\title{
Sources and Sociology Concerns of Financing the Innovation Activities in Russia
}

\author{
Budovich Lidia Sergeevna ${ }^{1, *}$ and Nikolaeva Olga Yurievna ${ }^{2}$
}

\author{
${ }^{1}$ Department of Economics and Innovative Entrepreneurship, MIREA - Russian Technological University \\ (RTU MIREA), Moscow, Russian Federation \\ ${ }^{2}$ Department of Economics and Innovative Entrepreneurship, Faculty of Economics and Law, MIREA - \\ Russian Technological University (RTU MIREA), Moscow, Russian Federation
}

\begin{abstract}
The innovation abilities of an enterprise and the feasibility of an innovative project always depend on financing. We can say that the main issue is the assessment of funds required for the implementation of an innovation and the analysis of their possible sources. In this paper, different mechanisms of financing and allocation of financial resources and their impact on innovative performance were examined. In general, financing sources of the institutes in different countries have adopted different mechanisms to provide and allocate resources from the range of public funding to private financing. But the amount varies from country to country so that in European institutions most government funding and the United States, private financing is the predominant form of financing. Some governments subsidize the supply side (higher education institutions), some on the demand side (customers), and some on both sides of the higher education services market. In general, negotiation-based and formula-based allocation, personnel-based allocation, student-based allocation, per capita cost, priority-based, and performance-based allocation are among the mechanisms used in this regard. The results of this article showed that the mechanisms of allocating and allocating resources in higher education play the role of policy-making and guiding the behavior of actors and can affect the performance of universities and institutions of higher education at the macro and micro level (individual). In the area of funding, graduates should contribute to the financing of universities, and in the area of allocation, performance-based allocation mechanisms should be used to achieve greater efficiency, accessibility, and equity.
\end{abstract}

Keywords: Innovation, finance, sociology, the education system.

\section{INTRODUCTION}

The main traditional sources of funds for any project are borrowed and own financing. As the market economy develops, new forms and sources of project financing may be discovered (Naumova and Gordeeva, 2019; Budovich 2019). Their structure is subject to changes depending on market outcomes, global and domestic financial and economic situation, the financial strength of organizations, etc. The sources of equity capital (except for profit) include depreciation charges allocated to the fixed assets and reimbursement of the intangible assets. Thanks to these deductions, the enterprise can (along with other conditions) carry out the expanded reproduction and implement the principle of self-financing. Self-financing of enterprises is provided by both internal and external sources of financing (Nikolaeva 2020; Tkachenko 2019). Private and public offerings to investors can be used to raise equity capital. A private offering is the private placement of shares for selling to one investor or a narrow circle of individual investors (insurance companies, banks, investment companies, individuals). The latter can only sell the acquired shares to the original owners.

*Address correspondence to this author at the Department of Economics and Innovative Entrepreneurship, MIREA - Russian Technological University (RTU MIREA), Moscow, Russian Federation; E-mail: budovich@mirea.ru
Innovation is the process that begins with an idea, continues as the invention progresses, or undergoes major changes, resulting in the launch of a new product, process, or service (Borrás \& Edquist 2019). Innovation is recognized as the most important source for economic development and growth of companies (Hilorme et al., 2019); As a result, politicians, entrepreneurs, and researchers are increasingly interested in how to increase innovation in the organization. According to the accounting literature Caplinska\&Ohotina, 2019; Strielkowski et al., 2019) the ability of companies to meet customer expectations depends on their ability to innovate and offer new products at competitive prices. Innovation is one of the key drivers for sustainable competitive advantage and also one of the key challenges for small and medium businesses. This requires companies to manage and improve themselves in the face of fierce business competition through innovation, financial and economic performance; As a result, the factor of innovation in the accounting system is a determining necessity in modern organizations (Yankovskaya et al., 2020). Companies try to gain a competitive advantage in the market by creating added value for the customer. To achieve this goal, they choose one of the strategies such as price leadership, differentiation, orientation, and focus on differentiation (structures that affect innovation) (Souto, 2012). Although competitive 
strategies are achieved separately in different ways, innovation is one of the rare resources that allow companies to differentiate themselves in response to competitors (Yan et al., 2014). By emphasizing innovation, companies use the opportunities in the market to grow and succeed in advancing their goals and achieve better financial and economic performance (Grilli, et al., 2018). Also, companies, in their production and non-production structure, by increasing innovation and reducing product costs, achieve increased productivity and increase profits, which has a significant impact on increasing the country's competitive capacity.

\section{METHOD}

When the gross financing requirements for the project are determined, the company's management reviews the possible forms and sources of financing. The classification is given in Table 1.

In recent years, the initial public offering (IPO) to external investors has become widespread to attract more investors and thus to raise the company's equity capital (especially at the final stage of the innovative project implementation). It means the public securities offering, including the listing of securities on the stock exchange or other securities market operators. The IPO process is preceded by the decision to restructure an innovative company into an open public corporation (going public), which involves selling a part of the equity to external investors and further entering the open markets. This process is possible only at the final stage of the implementation of the innovative project. The floating supply of the company's securities on the foreign stock exchanges cannot exceed $25 \%$ of all its shares issued.

\section{RESULTS}

Structuring of a company into an open (public) corporation with access to open markets has its advantages and disadvantages. The advantages are the following:

1) the opportunity to diversify investments among various financial instruments;

2) easy and low-cost fundraising from external sources in the future, since the company, as a result of the public offering and the publication of information, will be known to potential investors, and their credibility to the company will increase;

Table 1: Financing of Innovative Projects

\begin{tabular}{|c|c|}
\hline Forms of financing & Sources of financing \\
\hline $\begin{array}{l}\text { 1. Equity financing of innovations (at the expense of } \\
\text { own internal and external financial resources) }\end{array}$ & $\begin{array}{l}\text { Charter capital (original capital - contributions of the founders and raised capital - } \\
\text { additional contributions of the founders or attracting new investors by selling them a } \\
\text { part of additional issues of new shares) } \\
\text { Profit } \\
\text { Depreciation deductions } \\
\text { Intangible assets } \\
\text { Funds paid by insurance companies in the form of compensation for losses from } \\
\text { natural disasters, accidents, etc. }\end{array}$ \\
\hline $\begin{array}{l}\text { 2. Debt financing (at the expense of borrowed } \\
\text { financial resources) }\end{array}$ & $\begin{array}{l}\text { Government and corporate bonds } \\
\text { Funds of credit institutions (including banks) - loans, etc. }\end{array}$ \\
\hline 3. Public financing & $\begin{array}{l}\text { The federal budget of the Russian Federation } \\
\text { The Republican budgets (budgets of the subjects of the Federation) } \\
\text { Local (municipal) budgets } \\
\text { Non-budgetary funds }\end{array}$ \\
\hline 4. Mixed financing & $\begin{array}{l}\text { Funds of the budget investment fund } \\
\text { Public-private partnership (PPP) } \\
\text { Funds from private companies and individual investors } \\
\text { Closed-end mutual funds } \\
\text { Investments of insurance companies and non-governmental pension funds } \\
\text { Funds of foreign investors, etc. }\end{array}$ \\
\hline 5. New forms of financing & Leasing; Mortgage; Crowdfunding; Crowdinvesting \\
\hline
\end{tabular}


3) the potential liquidity of securities of a public corporation, which is highly unlikely in a closed joint-stock company (ZAO): it is difficult to sell securities to external investors, while other cofounders and owners of the company possibly do not want to buy shares of their company because of the possible financial risk;

4) the significant market extension, that is difficult to implement in a closed joint-stock company, etc.

Disadvantages of restructuring a company into a public corporation:

1) concerns of the company's management - as its owners - to lose real control of it;

2) the threat of the company acquisition by new investors in the external market through the buyout;

3) high expenses (especially for small innovative companies) for the preparation of quarterly and annual reports, publication of reports, and disclosure of confidential information;

4) inevitable and sufficiently high initial organizational costs of IPO (advertising, promotion of the company's brand, payment for financial and other services);

5) high payment for the underwriting services for the issue and placement of shares - almost all issues of securities are carried out on terms of the guaranteed subscription. So the risks of underwriting banks are relatively high and, as a result, the payments for the risks and underwriting income are also high. It is no coincidence that investment underwriting banks often organize syndicates to minimize risks that, if such is the case, are shared among the syndicate members.

Projects financing through IPO in the long term may provide for an increase in the company's market capitalization since it is likely that its credit rating will raise, the image in the business environment will improve, demand for its financial assets from potential investors will increase, that, as the result, will bump up its equity capital. Its formation can also be carried out at the expense of such a financial source as the state budget allocation by way of a grant. If profit and depreciation charges allow an enterprise to in one way or another ensure its financial stability and carry out expanded reproduction, then budget sources of financing innovative projects are globally targeted and allow to a greater extent to achieve the community of interests of organizations and the state, enterprises, and regions.

At the final stage of the implementation of the innovative project, in the process of innovative companies' development and reorganizing into open joint-stock companies, it becomes possible to use such external sources of innovative financing for the Russian Federation as the international placement of ordinary shares in the form of depositary receipts (DR) to increase the equity capital. These are certificates confirming the rights of their holders to a certain number of depositary shares, including the securities denominated in a foreign currency, confirming the ownership of foreign company shares, issued by a special bank - the depositary of the country of placement. The American Depositary Receipts (ADR), first issued in 1927, are widely known. They are denominated in dollars and can be issued both in the United States and abroad.

Nowadays, the global depositary receipts (GDR) and the European depositary receipts (EDR; only for the eurozone countries) get more widespread (depending on the stock trading market). To obtain permission to sell its shares in the form of depositary receipts, an innovative company (being an open jointstock company) must fulfill the following conditions: 1) register all share issues with the FFMS of Russia (Federal Financial Markets Service); 2) include these shares in the form of depositary receipts in the quotation lists of the domestic exchanges (RTS or MICEX). At present, the American depositary receipts of Russian companies (MTS, VimpelCom, Mechel, etc.) are traded on the New York Stock Exchange. The ADRs of Lukoil, Sibneft, Surgutneftegaz, Rostelecom, and others are traded on the London Stock Exchange. Disadvantages of debt financing for innovative activities through the issuance and placement of depositary receipts are a) availability only to large and relatively well-known enterprises; b) the high cost of issuing and selling depositary receipts; c) the strict requirements and rules in the country of placement, etc.

Unlike simple investment projects, innovative projects can be financed from these sources of fundraising commonly at the final stage of the project, 
when the result of its implementation will be a large total revenue. The decision on the state financing of individual innovative projects depends on 1) the expected performance of the project; 2) its social significance; 3 ) the pay-back period. Currently, budget financing of projects (the state funding) is carried out in two ways - within the program for the competitive allocation of investment and innovation resources and within the federal and republic national projects (projects that are of particular importance for the social and economic development of the country - defense, communications, research, and development, etc.). This practice is also widely used at the regional level, taking into account the economic and social (including environmental) consequences of the implementation of innovative solutions for residents of a particular region of the Federation.

Lease and mortgage financing can also be included in the debt financing sources. However, taking into account their difference from other sources of debt financing, these methods can be considered as specific (non-standard) sources of financing innovations.

In recent years, specific sources of financing innovation have become widespread in different countries. These primarily include leasing (from the English lease - lease, leased assets, leasing agreement). Using various types of leasing (financial, operating leasing, sale and leaseback, combined), it is possible to achieve the best social and economic results in the development of innovative solutions. The primary benefits of leasing in comparison with a loan: 1 ) it is easier for a company to purchase assets (for example, necessary equipment) using leasing than a loan; 2) lease payments are recorded to the production cost of the lessee in full and so reduce taxable income; 3) leasing does not require immediate payments, etc. The main disadvantages of leasing: a) mandatory advance payment in the amount of $25-30 \%$ of the transaction cost; b) as a rule, the final cost of lease payments is higher than the purchase of equipment on credit, etc.

\section{DISCUSSION}

In the Russian Federation, leasing relations are regulated by the Federal Law "On Financial Lease (Leasing)". Being a long-term agreement that provides for the complete depreciation of the leased equipment paid at the expense of the lessee, the financial (capital) leasing is cost-efficient primarily for the owner of the property since it significantly reduces his risk and allows the lessor to receive regular payments from the lessee for the use of this property. The financial leasing agreements do not allow the early termination of the lease, which provides the property owner with the required rate of return (Urinov, 2020). Upon expiry of the leasing agreement, the lessee can return the leased property, prolong the agreement or conclude a new agreement, as well as by the leased property at the residual value, often it is just nominal. If the manager of an innovative company has faced the problem of choosing the purchase of the necessary equipment using a loan or a lease, then he will inevitably compare the costs of these credit instruments based on the financial equivalence of payments. The leasing and the loan terms can be compared by calculating the profitability for the same period, i.e. based on the discounted cash flow method.

Unlike financial leasing (Frolova et al., 2020), an operating lease involves not only financing but also maintenance of the leased property by the representatives of the lessor. Moreover, the payment for the maintenance of the leased equipment is added to the lease payments. This type of lease provides the lessee with the right to early termination of the agreement. The operating lease agreement is usually concluded for a period from one to three years. Since this type of leasing often involves the provision of various services for the installation and routine maintenance (including repair) of the leased equipment, it is also called the service lease. Operating leasing allows the lessee to 1 ) get rid of out-of-date machinery and equipment promptly and replace them with more productive analogs; 2) to get rid of the leased property due to changes in market conditions and, as a result, the inevitability of business changes. This is especially important for innovative businesses.

The terms of operating lease are generally more beneficial for the lessee: the possibility of early termination of the lease makes it possible to get rid of out-of-date equipment promptly and replace it with a more high-tech and competitive one. Moreover, the lessee can quickly terminate this type of activity and return the equipment to the owner before the expiry date of the agreement, and significantly reduce the total expenses for liquidation or reorganization of production that can be crucial in case of adverse circumstances. At the same time, operating leasing has the following features: 1) payments are higher 
compared to other types of leasing; 2) advance payments and prepayment; 3) the agreement provisions include penalties in case of early termination of the lease; 4) other provisions that reduce and partially compensate for the risk of property owners.

With the development of such a specific source of financing as leasing, the scope of services provided by the lessor to the lessee is significantly expanding. In practice, leasing agreements often combine the features of both financial and operating leasing, so we can talk about the combined leasing. For example, they began to include the cancellation clause, commonly used in operating leases, in the financial lease agreements.

In recent years, the sale and leaseback vehave become widespread. specifically, the organization that owns land, buildings, equipment, machinery sells all this property and at the same time concludes an agreement on the leasing of certain types of property for a certain period. In this case, the payments for leased property come to the new owner and the lessor in equal shares, like in the conventional lending or mortgage system. The leaseback agreement can be regarded as a special type of financial lease. The main difference is that the lessor provides the former property owners with the opportunity to use equipment that has already been in operation, and not to purchase new equipment from a manufacturer or distributor.

A leasing deal (especially for a small business) involves high financial risks. However, the risk of equipment lease is justified due to the high future income from the implementation of innovations. In practice, the leading position among the leasing property in the Russian Federation is occupied by highly liquid equipment (various types of vehicles, farm machinery, etc.).

The use of any type of leasing is intended to (taking into account the provisions of the Federal Law "On Financial Leasing (Lease)" and the Tax Code of the Russian Federation) mutual benefit of both the lessee and the lessor. The " identity" of their interests is largely determined by the tax considerations: 1) methods of depreciation; 2) tax rates; 3) investment tax credit (ITC); 4) an opportunity to use the accelerated depreciation method, the alternative minimum tax (AMT).

Another specific form of financing innovation is mixed financing like the public-private partnership
(PPPs) (Näyhä 2020). This is a relatively new organizational form for the RF and appeared with the objective stimulate innovative activities. Its development in different countries is primarily driven by the processes of creating the regional industrial and social infrastructure: the construction of highways, sports and recreation centers, etc. Public-private partnership is often founded for the creation of technology parks, to join efforts of different experts (scientists, engineers, designers) to solve specific problems of innovative development. Examples include science campuses, innovation and business centers, the state company Rusnano, and the Russian Venture Corporation.

Mixed financing in the form of public-private partnerships is used in the creation of technopolises. Usually, the term "technopolis" is understood as either an industrial complex or a town where a concentration of education and culture, science and technology, science-intensive business, and venture capital trigger a "chain reaction" of scientific and business activity. Technopark - Zelenograd (established in 1997) is one of the most famous technopolises. Although the goals of its creation were connected with the innovative development, in practice, due to insufficient state funding and other reasons, it could not accelerate the scientific and technological progress.

The public-private partnership cannot successfully develop without sufficient financial resources. The attraction of private investors remains the major problem. One should take into account the fact that investments in innovative projects, as a rule, are characterized by 1) uncertainty of the results; 2) long payback period; 3) unpredictable social, economic, and environmental impacts of the innovative project; 4) high risks, etc. Due to the above, we cannot expect significant cash injections into the public-private partnerships from individual investors and small private businesses.

Only government intervention, its financial and administrative resources can ensure the development of public-private partnerships. However, there is a real danger of misallocation of the federal financial resources. Therefore, the requirements for founders of various innovative structures have been tightened: enterprises must present a more detailed innovative business plan, justify in detail the needs of an innovative company in financial resources, etc. The public-private partnership is an integrated system of 
public and private investments, consolidation of funds to establish an inextricable connection between science, industry, and capital. Ultimately, the PPP is aimed at engineering development and the implementation of scientific results in production. The positive aspects of the PPP are indisputable: R\&D laboratory experiments may be taken as the basis for the creation of fundamentally new equipment and technology in various fields of the national economy and contribute to the acceleration of scientific and technological progress in the country. As a result, the number of knowledge-intensive enterprises will inevitably grow.

The mortgage can also be a specific source of financing for innovative projects (from the Greek hipotheka - pledge) - a long-term loan for investment purposes against the security of the property. However, the logical question arises: what is the connection between mortgage and innovations? The development of an innovative idea and its implementation requires great expenses at the initial stage of the innovative project implementation. It is difficult to find investors who want to finance a project with a high risk, longterm payback, and uncertainty of the future results. In the case of a mortgage of an enterprise as a property complex, the right of pledge extends to all property inside.

\section{CONCLUSION}

The use of mortgage financing of innovative projects in high-risk businesses is not very widespread because the equipment of high-tech industries can be very specialized and, therefore, low liquid or non-liquid at all. This also applies to the mortgaged intangible assets and securities. Without the participation of the state, it is difficult to attract specific borrowed sources of innovation financing in the form of mortgage loans. It may benefit the most from a variety of social innovations, largely due to perceived risks associated with return on investment. Significant barriers and disincentives exist within current mainstream economic structures despite a growing interest and willingness of some individuals and organizations capable of channeling private capital into innovative social and environmental products or processes.

In the conclusion of the study, it is necessary to review new methods of financing innovative activities, including crowdfunding and crowd investing. Such forms of investment are widespread in Western countries and proved to be very effective instruments of financing innovative activities. Crowdfunding is the voluntary financing of an innovative project by the interested parties to receive income in the future. Further empirical research is needed to evaluate the financial innovation activities in various fields to enhance the optimal procedure. Crowd investing differs in the fact that investors receive shares in a startup with the risk of losing their investment.

\section{REFERENCES}

Borrás, S., Edquist, C. (2019). Holistic Innovation Policy: Theoretical Foundations, Policy Problems, and Instrument Choices. Oxford University Press. https://doi.org/10.1093/oso/9780198809807.001.0001

Budovich, L., (2019). Special aspects of innovative product development by knowledge-intensive businesses in the current economic conditions. International Journal of Innovative Technology and Exploring Engineering, 8(12), p. 2053-2055

https://doi.org/10.35940/ijitee.L3255.1081219

Caplinska, A., \&Ohotina, A. (2019). Analysis of financial literacy tendencies with young people. Entrepreneurship and Sustainability Issues, 6(4), 6. https://doi.org/10.9770/jesi.2019.6.4(13)

Frolova, I. I., Nosov, V. V., Zavyalova, N. B., Dorofeev, A. E., Vorozheykina, T. M., \& Petrova, L. I. (2020). Labor opportunism as a blocking factor for the innovative development of industrial enterprises. Entrepreneurship and Sustainability Issues, 7(3), 2228-2242. https://doi.org/10.9770/jesi.2020.7.3(51)

Grilli, L., Mazzucato, M., Meoli, M., \&Scellato, G. (2018). Sowing the seeds of the future: Policies for financing tomorrow's innovations. Technological Forecasting and Social Change, 127, 1-7. https://doi.org/10.1016/j.techfore.2017.10.021

Hilorme, T., Zamazii, O., Judina, O., Korolenko, R., \&Melnikova, Y. (2019). Formation of risk mitigating strategies for the implementation of projects of energy saving technologies. Academy of Strategic Management Journal, 18(3), 1-6.

Näyhä, A. (2020). Finnish forest-based companies in transition to the circular bioeconomy-drivers, organizational resources and innovations. Forest Policy and Economics, 110, 101936. https://doi.org/10.1016/j.forpol.2019.05.022

NaumovaYu.A., Gordeeva I.V. (2019). Analysis of mathematical models for description of the fractional composition of disperse elastic fillers. Russian Technological Journal.7(5):62-78. (In Russ.) https://doi.org/10.32362/2500-316X-2019-7-5-62-78

NikolaevaO.Yu. (2019). Review of modern tools for financial support of innovative activities. Economic sciences, 2020, 2, p. 2325.

Strielkowski, W., Kalyugina, S., \&Mukhoryanova, O. (2019). Managing Human Potential and Youth Social Entrepreneurship in Peripheral Regions. Management Research \& Practice, 11(3).

Souto, J.E. (2012). Innovation, Entrepreneurship and Technologybased Companies in Spain: Critical Factors and Impact on the Competitiveness of the Economy. Netbiblo, Spain

Tkachenko, V., Kuzior, A., \&Kwilinski, (2014). A. Introduction of artificial intelligence tools into the training methods of entrepreneurship activities. Journal of Entrepreneurship Education, 22(6), 1-10.

Urinov, B. N. (2020). Theoretical Aspects Of Organizational Behavior And Corporate Culture. Economics and Innovative Technologies, 2020(2), 15-22. 
Yan, Q., Amama, S., and T. Rajesh. (2014). Environmental and Social Disclosures: Link with Corporate Financial Performance. The British Accounting Review, Vol. 48, No. 1, Pp. 102-116.

https://doi.org/10.1016/j.bar.2014.10.007
Yankovskaya, V.V., Osipov, V.S., Zeldner, A.G., Panova, T.V. and Mishchenko, V.V. (2020), "Institutional matrix of social management in region's economy: stability and sustainability vs innovations and digitalization", International Journal of Sociology and Social Policy, Vol. 4, 34-56. https://doi.org/10.1108//JSSP-03-2020-0088

DOI: https://doi.org/10.6000/1929-4409.2021.10.56

(C) 2021 Sergeevna and Yurievna; Licensee Lifescience Global.

This is an open access article licensed under the terms of the Creative Commons Attribution Non-Commercial License (http://creativecommons.org/licenses/by-nc/3.0/) which permits unrestricted, non-commercial use, distribution and reproduction in any medium, provided the work is properly cited. 